\title{
Use of Topographic Map Evidence to Test a Recently Proposed Regional Geomorphology Paradigm: Wind River-Sweetwater River Drainage Divide Area, Central Wyoming, USA
}

\author{
Eric Clausen \\ Jenkintown, PA. USA \\ Email: eric2clausen@gmail.com
}

How to cite this paper: Clausen, E. (2019) Use of Topographic Map Evidence to Test a Recently Proposed Regional Geomorphology Paradigm: Wind River-Sweetwater River Drainage Divide Area, Central Wyoming, USA. Open Journal of Geology, 9, 404-423. https://doi.org/10.4236/ojg.2019.98027

Received: July 13, 2019

Accepted: August 11, 2019

Published: August 14, 2019

Copyright () 2019 by author(s) and Scientific Research Publishing Inc. This work is licensed under the Creative Commons Attribution International License (CC BY 4.0).

http://creativecommons.org/licenses/by/4.0/ (c) (i) Open Access

\begin{abstract}
Topographic map evidence from the Wyoming Wind River-Sweetwater River drainage divide area is used to test a recently proposed regional geomorphology paradigm defined by massive south- and southeast-oriented continental ice sheet melt water floods that flowed across the entire Missouri River drainage basin. The new paradigm forces recognition of an ice sheet created and occupied deep "hole" and is fundamentally different from the commonly accepted paradigm in which a pre-glacial north- and northeast-oriented slope would have prevented continental ice sheet melt water from reaching or crossing the Wind River-Sweetwater River drainage divide. Divide crossings (or low points) are identified as places where water once flowed across the drainage divide. Map evidence is interpreted first from the accepted paradigm perspective and second from the new paradigm perspective to determine the simplest explanation. Both paradigm perspectives suggest south-oriented water crossed the drainage divide, although accepted paradigm interpretations do not satisfactorily explain the large number of observed divide crossings and are complicated by the need to bury the Owl Creek and Bridger Mountains to explain why the Wind River now flows in a north direction through Wind River Canyon. New paradigm interpretations explain the large number of divide crossings as diverging and converging channel evidence (as in flood-formed anastomosing channel complexes), Owl Creek and Bridger Mountain uplift to have occurred as south-oriented floodwaters carved Wind River Canyon, and a major flood flow reversal (caused by ice sheet related crustal warping and the opening up of deep "hole" space by ice sheet melting) as being responsible for the Wind River abrupt turn to the north. While this test only addresses topographic map evidence, Occam's Razor suggests the
\end{abstract}


new paradigm offers what in science should be the preferred Wind River-Sweetwater River drainage divide origin interpretations.

\section{Keywords}

Beaver Divide Escarpment, Continental Ice Sheet Melt Water Floods, East-West Continental Divide, Great Divide Basin, Wind River Basin, Wind River Mountains

\section{Introduction}

\subsection{Statement of the Problem}

Paradigms according to Kuhn [1] are frameworks of rules governing how a scientific research community conducts its research and by themselves are neither correct nor incorrect, but are judged on their ability to explain evidence and to open up new research opportunities. Recently Clausen [2] proposed a new regional geomorphology paradigm (new paradigm) defined by massive south- and southeast-oriented continental ice sheet melt water floods that once flowed across the entire present-day Missouri River drainage basin, including what are today high mountain and plateau areas. This new paradigm is fundamentally different from the commonly accepted regional geomorphology paradigm (accepted paradigm) in which a pre-glacial north-, northeast-, and east-oriented slope would have prevented continental ice sheet melt water from reaching many Missouri River drainage basin areas especially in Montana, Wyoming, southwestern North Dakota, western South Dakota, Nebraska, Kansas, and Colorado, much less from flowing across what in late Cenozoic time were high plateau areas and mountain ranges. The study reported here uses detailed topographic maps of the Wyoming Wind-Sweetwater River drainage divide area (which is located within the Missouri River drainage basin and also near the North American east-west continental divide) to test the new paradigm expectation that topographic map evidence from the Wind River-Sweetwater River drainage divide area is more satisfactorily explained from a new paradigm perspective than from an accepted paradigm perspective.

\subsection{Geographic Setting of the Wind River-Sweetwater River Drainage Divide Area}

The Wind River (number "1" in Figure 1) originates near a deep northwest Wyoming mountain pass that crosses North America's east-west continental divide and flows in a southeast direction between the Wind River Mountains ("A") and the Absaroka ("F") and Owl Creek Mountains ("B") to enter the west central Wyoming Wind River Basin. Once north of where the northwest-to-southeast oriented Wind River Mountains end, the southeast-oriented Wind River abruptly turns in a north direction to cut between the Owl Creek Mountains and the Bridger Range ("C") in the 1 kilometer deep Wind River Canyon, before entering 


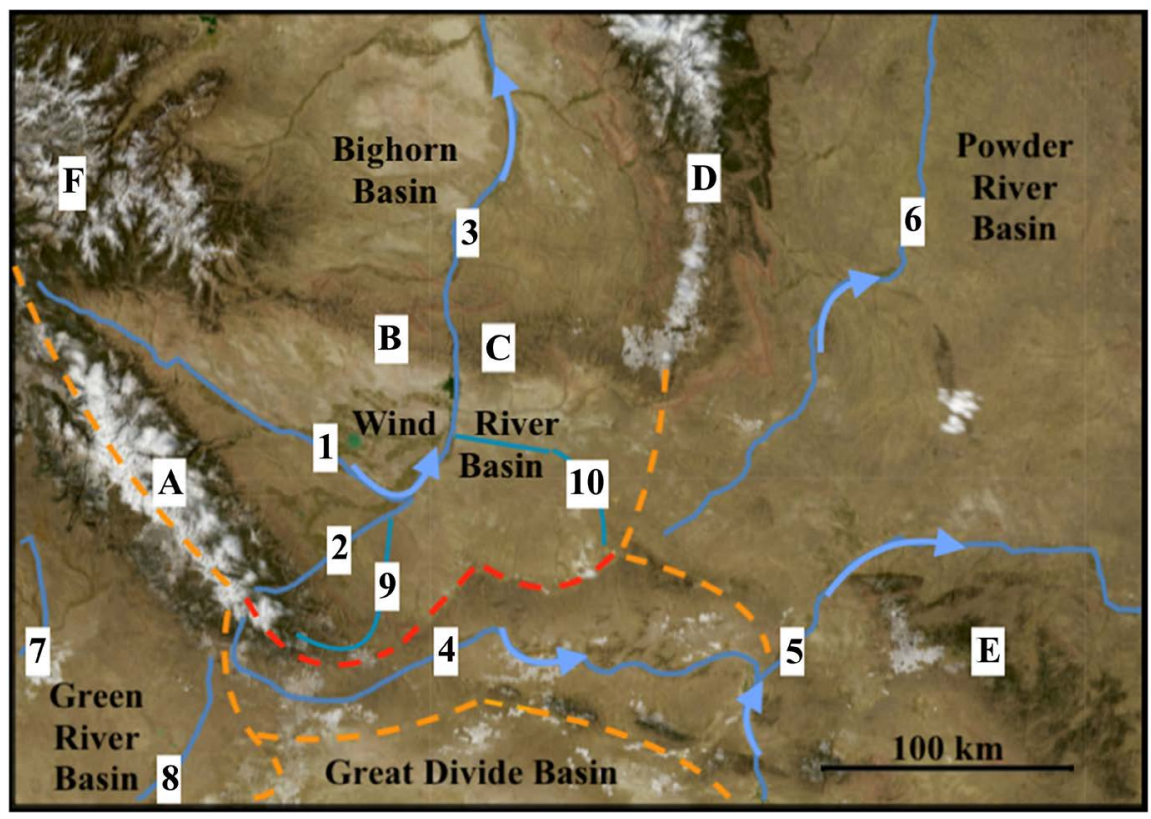

Figure 1. Modified USGS National Map website imagery showing Wyoming mountains: A-Wind River Mtns, B-Owl Creek Mtns, C-Bridger Range, D-Bighorn Mtns, E-Laramie Range, F-Absaroka Mtns.; and rivers: 1-Wind River, 2-Popo Agie River, 3-Bighorn River, 4-Sweetwater River, 5-North Platte River, 6-Powder River, 7-Green River, 8-Little Sandy Creek, 9-Beaver Creek, and 10-Deer-Poison Creek. The red dashed line shows the Wind-Sweetwater River drainage divide and orange dashed lines show other divides.

the Bighorn Basin where the river name changes to become the Bighorn River (" 3 "). The Bighorn River in Montana joins the northeast-oriented Yellowstone River, which joins the southeast-oriented Missouri River with its water eventually reaching the Gulf of Mexico. Also identified in Figure 1 is the Popo Agie River ("2"), which originates high in the Wind River Mountains before flowing in a northeast direction to join the north-oriented Wind River.

The Sweetwater River ("4") originates in the Wind River Mountains and flows in a south and southeast direction before turning in a northeast, southeast, and then more of an easterly direction to reach the North Platte River (" 5 ") with its water eventually reaching the Missouri River. Almost adjacent to south-oriented Sweetwater River headwaters are south-oriented Little Sandy Creek (" 8 ") headwaters, which to the south of Figure 1 join the Big Sandy River and then the south-oriented Green River ("7") with its water flowing to the Colorado River. The orange dashed line following the Wind River Mountains crest until it turns to continue in a south direction between the Sweetwater River (east) and Little Sandy Creek (west) is North America's east-west continental divide. Near Figure 1 south edge that orange dashed line splits with one branch continuing south and the other branch proceeding in an east direction between the Sweetwater River drainage basin and the Great Divide Basin. The Great Divide Basin is a large area of internal drainage located along the east-west continental divide with the relatively narrow east-oriented Sweetwater River drainage basin located to the north and south-oriented Colorado River tributary drainage basins to the 
south.

The focus of the study reported here is the Wind River-Sweetwater River drainage divide and is shown by the red dashed line. At its west end the Wind River-Sweetwater River drainage divide follows the Wind River Mountains crest (with some elevations exceeding 3500 meters) and is the boundary between northeast-oriented Popo Agie River headwaters and south-oriented Sweetwater River headwaters. Further to the southeast, but still within the uplifted Wind River Mountains area, the Wind River-Sweetwater River drainage divide is located between southeast-oriented Rock Creek (flowing to the Sweetwater River) and the headwaters of southeast-, east-, and north-oriented Beaver Creek (flowing to the Wind River). To the east of the Wind River Mountains southeast end the red dashed line turns in a northeast direction as the drainage divide follows the Beaver Divide escarpment rim. The north-facing Beaver Divide escarpment marks the boundary between the Wind River Basin (north) and the Sweetwater Plateau (south). The Beaver Divide escarpment continues in an eastward direction to where the red dashed line splits into two orange dashed lines indicating the end of the Wind River-Sweetwater River drainage divide. Elevations along the Beaver Divide escarpment rim range from about 2070 meters (west) to about 2400 meters (east).

The east-oriented Sweetwater River drainage basin separates what is today the north-oriented Wind-Bighorn River drainage basin from the North American east-west continental divide (the Great Divide Basin) and the Sweetwater River turns in a south direction to join the north-oriented North Platte River (“ 5 "). Note how the North Platte River also turns from a north direction to an east and southeast direction where it has cut a 300-meter deep or deeper canyon across the Laramie Range ("E") northwest end. To the south of Figure 1 the North Platte River originates in northcentral Colorado mountains and flows in a northwest and north direction to reach Figure 1 map area. In addition to the canyon cut across the Laramie Mountains northwest end the North Platte River has also cut deep canyons across other uplifted structures. Deep canyons cut across mountain ranges and other uplifted geologic structures, such as Wind River Canyon and the North Platte River canyons, in addition to the river drainage routes themselves, are critical evidence any regional geomorphology paradigm must explain.

\subsection{Previous Work}

When testing whether or not a new paradigm can satisfactorily explain a given set of observed evidence three types of previous work are important. First is paradigm neutral previous work describing, but not interpreting relevant evidence. Second is previous work in which relevant evidence has been interpreted according to accepted paradigm rules. And third is previous work in which the new paradigm rules are defined and/or have demonstrated an ability to explain similar sets of relevant evidence. 
United States Geological Survey (USGS) topographic maps are excellent examples of paradigm neutral previous work and were used in the study described here. Geologic maps also contain paradigm neutral previous work, although they can include paradigm influenced interpretations. Geologic maps used in the study reported here included the Geologic Map of Wyoming [3] and the Geologic Map of the Lander 30' × 60' Quadrangle, Fremont County, Wyoming [4]. Bedrock units shown on such maps are assumed to exist as described and where mapped. Geologic reports, even if written from a specific paradigm's perspective often include paradigm neutral descriptions such as the following, "The Beaver Divide of central Wyoming is a conspicuous escarpment in which as much as 2000 feet [610 meters] of Eocene, Oligocene, and Miocene nonmarine strata are exposed. It forms the boundary between two distinctive physiographic provinces, the Sweetwater Plateau and the Wind River Basin" [5] (although fundamentally different paradigms may interpret "Eocene", "Oligocene", and "Miocene" in different ways).

Geologic reports also contain paradigm-influenced interpretations such as, "It was at this time (early Oligocene) that the ... Wind River found its outlet to the north. The basins had been filled, and the peaks of the Owl Creek, the Bridger, and the Bighorn mountains, buried nearly to their summits by the soft Eocene deposits, presented no obstacle to the drainage. The greater raising of the Wind River and the Granite ranges at this time tilted the plain toward the north, and drainage in that direction was a natural consequence" [6]. Accepted paradigm ideas underlying these interpretations are summarized in a Mears [7] literature review, "following the end of [a] major deformation in the early mid-Eocene, the crests of the [Wyoming] mountains were lowered by erosion and the mountain valleys and broad intermontane basins were filled ... The rising level of Oligocene and Miocene deposits eventually lapped across the lower segments of the crystalline-cored uplands that finally had been eroded down to broad sub-summit surfaces surmounted by residual hills and peaks. At some time during this aggradational episode, broad regional uplift began to raise the mountains to their present-day elevations. The exhumation of the present broad basin floors and adjacent mountain valleys began in mid-Miocene time."

Fleshing out and helping to define the accepted paradigm Lillegraven and Ostresh [8] report, "Because of the extensive early Oligocene infillings of Wyoming's basins, a basic eastwardly grained drainage pattern ... was established ... Except for the late Oligocene pulse of uplift of the Wind River Range ..., the general landscape became evermore planar until about the middle of the Miocene ... Conditions then shifted during an interval of several million years that was characterized by alternative cutting and filling ... Finally, approximately the past 10 million years reflect the dominance of massive erosion ..., exhuming an essentially Eocene topography." Accepted paradigm interpretations such as this have led to drainage history interpretations illustrated by Galloway et al. [9] that show large aprons of [late Eocene and Oligocene] White River and later [early Miocene] Arikaree sediments filled the Wind River Basin and extended north- 
ward across the Bighorn Basin and eastward to the northern Great Plains.

Accepted paradigm interpretations consider Eocene, Oligocene, and Miocene sediments to have filled the intermontane basins and to have buried all but the highest mountain range crests while Wyoming's present-day drainage system evolved. Several workers, including Sinclair and Granger [10] and Mackin [11], describe how a north-oriented Bighorn River tributary eroded headward (probably during Oligocene time) from the Bighorn Basin. across the buried Owl Creek and Bridger Mountains to capture the southeast-oriented Wind River. Similar captures led to Wyoming's present-day drainage system. Once modern-day drainage routes had been established the rivers maintained their courses as they cut down through the sediment cover into the buried mountains to carve deep canyons, such as Wind River Canyon. Riihimaki et al. [12] state "The modern drainage network has partially exhumed most basins, creating broad depressions up to $\sim 1.5 \mathrm{~km}$ deep in easily eroded fine-grained sedimentary strata," which implies the modern-day Wind River exhumed the Wind River Basin.

According to accepted paradigm interpretations, after being captured (possibly in Oligocene time) the Wind River flowed in a north direction into the Bighorn Basin where it is now known as the Bighorn River, which in Montana joins the northeast-oriented Yellowstone River. The Yellowstone River now joins the Missouri River, but in northwest North Dakota an abandoned valley suggests the Yellowstone River once flowed into Canada [13] to join what the accepted paradigm considers the pre-glacial north-oriented Bell River drainage system [14]. The Missouri River route in eastern Montana, North Dakota, and South Dakota is usually interpreted to have formed along an ice sheet margin and abandoned valleys, such as the abandoned Yellowstone River valley, located to the north of the ice-marginal Missouri River valley, are considered pre-glacial in age. Because some of these abandoned valleys, including the abandoned Yellowstone River valley, are cut in easily eroded sedimentary rock White [15] argued ice sheet erosion should have destroyed them, but critics, including Gravenor [16] and Sugden [17], rejected White's hypothesis and reinforced the widely held accepted paradigm interpretation that ice sheets did not deeply erode the North American northern plains region bedrock.

The fundamentally different new paradigm is defined by immense south- and southeast-oriented continental ice sheet melt water floods that flowed across the entire Missouri River drainage basin including what are today high mountain ranges and plateau areas. This paradigm rule forces recognition of a thick continental ice sheet that created and occupied a deep "hole." The deep "hole" was created by deep ice sheet erosion (that destroyed all pre-glacial drainage routes (in other words abandoned valleys the accepted paradigm considers pre-glacial cannot be pre-glacial) and by ice sheet related crustal warping that raised mountain ranges and plateau areas as large south- and southeast-oriented melt water floods flowed across them (in other words, ice sheet related crustal warping raised the Rocky Mountain region and the mountain ranges within it). 
To date more than a dozen papers (similar to this paper) have been published in which detailed topographic map evidence for specific northern Missouri River drainage basin geographic regions has been interpreted from the new paradigm perspective. Clausen [2] summarizes a number of these new paradigm papers each of which demonstrates for specific northern Missouri River drainage basin geographic regions how the new paradigm explains previously unexplained detailed topographic map evidence. Several such papers demonstrate how topographic map evidence indicates north-oriented valleys eroded headward from a continental ice sheet location (where ice sheet melting was opening up space at the deep "hole's" southern end) to capture massive southeast-oriented ice-marginal floods [18] [19] [20]. Other papers describe topographic map evidence demonstrating how massive floods flowed across a rising Laramie Range [21] and a rising Black Hills uplift [22] and carved what is today a northern Montana east-west continental divide segment [23].

Another new paradigm paper [24] demonstrates how immense south-oriented floods and uplift of the Bighorn-Wind River drainage divide area to the north of this paper's study region explains Wind River Canyon erosion and previously unexplained drainage divide crossings (without burying the Owl Creek and Bridger Mountains). That paper demonstrates how prior to a drainage reversal that caused the melt water floods to flow into deep "hole" space, south-oriented melt water floods flowed across what is now the Bighorn-Wind River drainage divide and into the Wind River Basin and suggests the floodwaters continued in a south direction across the east-oriented Sweetwater River drainage basin and the Great Divide Basin to reach the southwest-oriented Colorado River. Further, the paper states the east-oriented Sweetwater River drainage basin is located along a deep "hole" rim segment, with the deep "hole" rim in Montana, Wyoming, and northern Colorado following the present-day east-west continental divide.

\section{Research Method}

This paper is one component of the author's much larger Missouri River drainage basin landform origins research project. The larger project was first done during the 1999-2001 time period by studying hard copy detailed topographic map mosaics to determine how the Missouri River drainage basin originated. Results were different from anything then in the published literature and could not be presented without hard copy detailed topographic map mosaics. The study was repeated during the 2011-2013 time period using National Geographic TOPO software and topographic maps with approximately 500 research notes in blog format now available at geomorphologyresearch.com. Studies such as the one presented here are being repeated for publication purposes.

The study described here investigated (from west to east) detailed topographic maps found at the USGS National Map website to identify low points or divide crossings where water can reasonably be interpreted to have flowed across what 
is today the Wind River-Sweetwater River drainage divide. Divide crossing elevations and depths were noted and map evidence and published geologic reports were used to determine probable flow directions. Closely spaced divide crossings were considered to have been eroded by either closely spaced stream channels or by diverging and converging channels. Identified divide crossings were also grouped as indicated in the results section and an attempt was made to explain each group's divide crossings first from the accepted paradigm perspective and second from the new paradigm perspective. Occam's Razor was next applied to determine which of the two paradigm perspectives provides the simplest explanations.

\section{Research Results}

\subsection{High Wind River Mountains: Sweetwater Gap}

Figure 1 shows where the Sweetwater River originates as a south-oriented river in the northwest-to-southeast oriented Wind River Mountains where peaks rise up to 1000 meters above a high-level erosion surface. To the northwest of the Sweetwater River headwaters the North American east-west continental divide follows the crest of the highest peaks and the high-level erosion surface on the southwest side slopes gently to the south, before a southwest-facing escarpment separates it from the Green River Basin to the south. Steidtmann et al. [25], referring to a region near where the Sweetwater River originates report, "volcanic clasts in conglomerate beds of the middle Eocene Bridger Formation in the southern Wind River Range came from the Absaroka volcanic field to the north. This indicates a drainage across what is now the crest of the range, and thus that there was little relief there in middle Eocene time." In other words, the south-oriented Sweetwater River headwaters may have originated at a time when large volumes of water flowed in a south direction from the Absaroka Mountains across what are today the Wind River Basin northwestern end and the high Wind River Mountains crest ridge.

Sweetwater Gap (floor elevation 3155 meters) is a 420-meter deep mountain pass carved into the Wind River Mountains crest ridge and links north- and northeast-oriented Middle Fork Popo Agie River headwaters with south-oriented Sweetwater River headwaters. Figure 2 provides a topographic map of Sweetwater Gap (identified by "A") and its relationship to south-oriented Little Sandy Creek, which is a Green River tributary with its water eventually reaching the Pacific Ocean. The letter "B" identifies a 300-meter deep divide crossing linking a northeast-oriented Middle Fork Popo Agie River tributary valley with the south-oriented Little Sandy Creek valley. The region has been glaciated and the deeper Little Sandy Creek valley has truncated the northeast-oriented Middle Fork Popo Agie tributary valley. The letter "C" identifies two much shallower divide crossings where south-oriented water flowed across the present-day east-west continental divide from the Little Sandy Creek valley into the south-oriented Sweetwater River headwaters drainage basin. Further to the south (and not seen) 


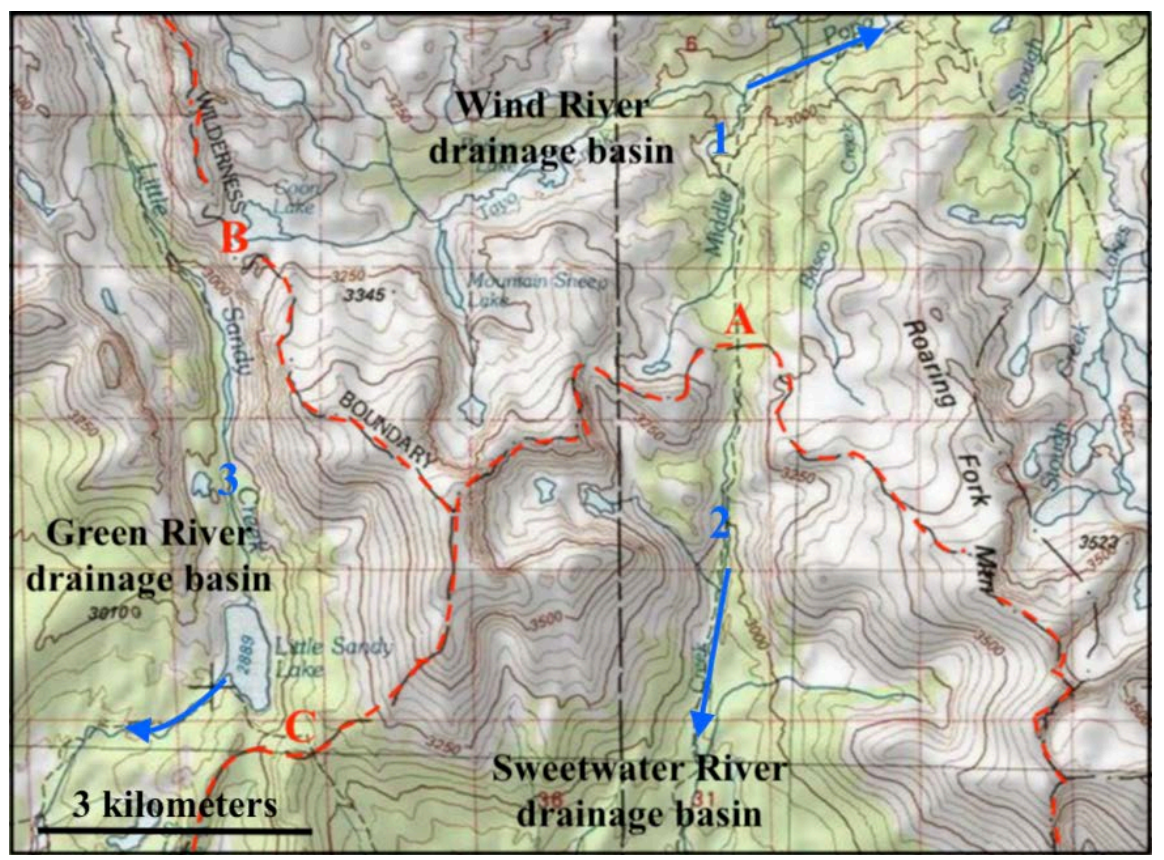

Figure 2. Modified topographic map from USGS National Map website identifying Sweetwater Gap ("A") and two divide crossings across the east-west continental divide discussed in the text. Blue numbers identify drainage routes: "1"-Middle Fork Popo Agie River. "2"-Sweetwater River, and " 3 "-Little Sandy Creek. Red dashed lines identify drainage divides with the drainage basins are labeled. The contour interval is 50 meters.

a southeast-oriented Sweetwater River tributary (Landers Creek) begins and flows near a 20-meter deep valley in which Little Sandy Creek is flowing. In other words, topographic map evidence suggests water from the Little Sandy Creek valley once flowed into the Sweetwater River drainage basin.

Based on work by Steidtmann and others both paradigms must require south-oriented water to have eroded the 420-meter deep Sweetwater Gap into a rising Wind River Mountains crest ridge before uplift diverted the water in a northeast direction. Where the two different paradigm interpretations differ relates to evidence seen in Figure 2 at location "B", where a 300-meter deep valley crosses the continental divide and links the south-oriented Little Sandy Creek valley with a northeast-oriented Middle Fork Popo Agie River tributary valley. The divide crossing at location " $\mathrm{B}$ " from the accepted paradigm perspective is probably best explained by glacial erosion that linked a valley glacier filling the Little Sandy Creek valley with a valley glacier filling the northeast-oriented Middle Fork Popo Agie River tributary valley. While recognizing that both valleys were subsequently glaciated the divide crossing at location "B" from the new paradigm's perspective is probably best explained if a southwest-oriented flood flow channel diverged from the south-oriented flood flow channel moving water through Sweetwater Gap and then converged with a south-oriented flood flow channel in what is now the south-oriented Little Sandy Creek valley. Wind River Mountains uplift subsequently reversed flow along what had been the diverging southwest-oriented flow route to create the northeast-oriented Middle Fork Po- 
po Agie River tributary with alpine glaciation later altering the valley. Divide crossings at location " $\mathrm{C}$ " and further to the south are probably best explained from the accepted paradigm perspective by alpine glacier melt water floods while from the new paradigm's perspective by diverging and converging flood flow channels.

\subsection{Wind River Mountains Southeast End: Beaver Creek Headwaters}

To the east and southeast of Figure 2 the Wind River-Sweetwater River drainage divide follows the high Wind River Mountains crest ridge for approximately fifteen kilometers with several shallower divide crossings notched into it. The 100-meter deep Christina Pass (floor elevation 3272 meters) links headwaters of the south-oriented Little Sweetwater River with headwaters of the northeast-oriented Little Popo Agie River (flowing to northeast-oriented Popo Agie River). The 200-meter deep Sioux Pass (floor elevation 2970 meters) links southwest-oriented East Sweetwater River headwaters with northeast-oriented Louis Creek headwaters (flowing to Little Popo Agie River). While alpine glaciers may have eroded some higher-elevation divide crossings, both paradigms can reasonably develop interpretations where south-oriented water eroded Christina Pass and Sioux Pass prior to the crest ridge uplift.

Granite Peak (elevation 3171 meters) is located to the southeast of Sioux Pass and marks where the Wind River-Sweetwater River drainage divide leaves the crest ridge and turns in a northeast direction between northeast-oriented Louis Creek and Rock Creek headwaters, although Rock Creek soon turns in an east-southeast direction to reach Figure 3 map area and eventually join the Sweetwater River. Interestingly a narrow northwest-to-southeast oriented 75-meter deep through valley (floor elevation 2754 meters) links the northeast-oriented Louis Creek valley with the Rock Creek valley and suggests water once flowed between the two valleys, which new paradigm rules make much easier to explain than the accepted paradigm rules.

After Rock Creek turns in an east-southeast direction southeast-oriented Beaver Creek originates to the north of the Wind River-Sweetwater River drainage divide and after flowing in a southeast direction turns at the Wind River Mountains southeast end in a north direction with its water eventually reaching the north-oriented Wind River. Proceeding in a southeast direction from Granite Mountain toward the Wind River Mountains southeast end additional through valleys cross the Wind River-Sweetwater River drainage divide and Figure 3 provides a topographic map of one of the westernmost of those divide crossings. The 100-meter deep through valley at location " $\mathrm{A}$ " has been cut in Precambrian quartz diorite by water that flowed from the Rock Creek valley to the Beaver Creek valley or vice versus. In the Channeled Scabland region (in Washington state) a catastrophic flood in which water spilled across drainage divides is used by Baker [26] to explain how diverging and converging dry valleys were eroded into erosion resistant bedrock and now cross drainage divides. 


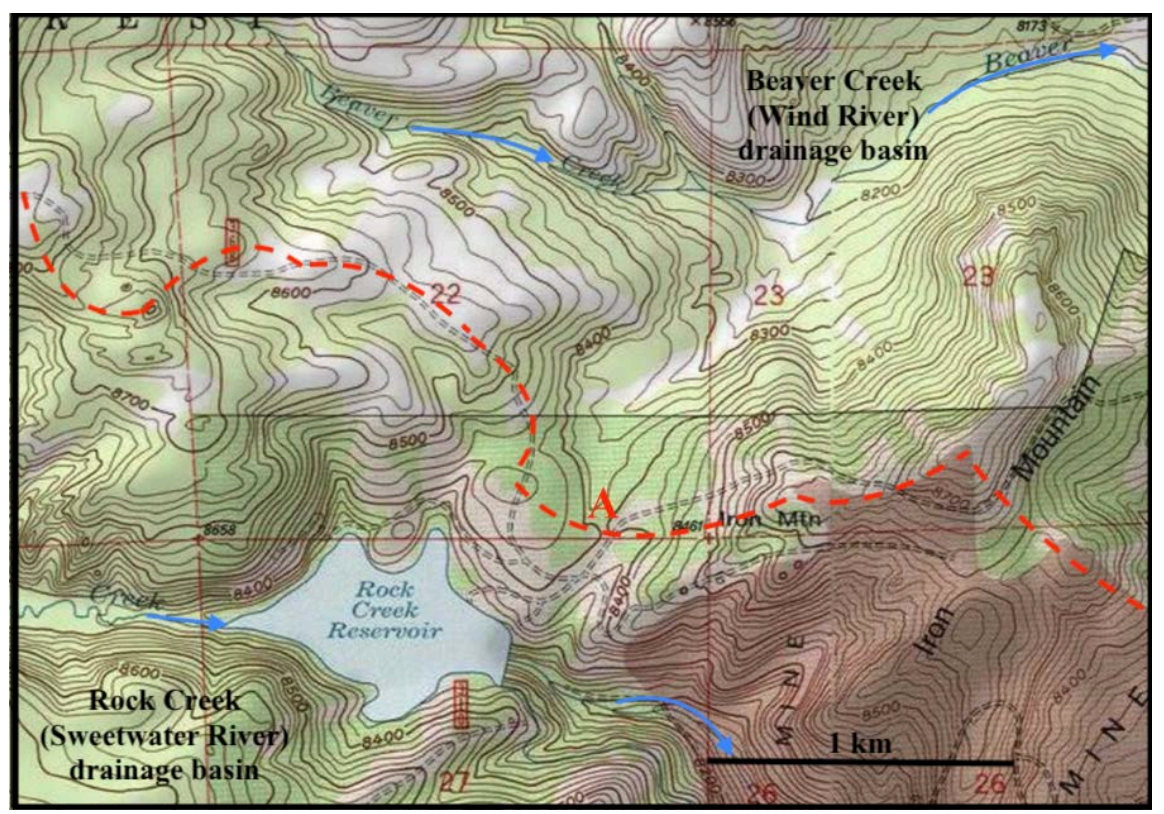

Figure 3. Modified topographic map from USGS National Map website identifying a 100-meter deep divide crossing linking the Beaver Creek (Wind River) drainage basin and the Rock Creek (Sweetwater River) drainage basin. The dashed red line shows the Wind River-Sweetwater River drainage divide. The contour interval is 20 feet (6 meters).

The Beaver and Rock Creek routes diverge in Figure 3 with Rock Creek flowing in a southeast and south direction to join the Sweetwater River. Further to the southeast (and not shown) headwaters of southeast- and east-oriented Little Beaver Creek (flowing to Beaver Creek) are on the north side of a valley (in which the Fort Stambaugh historic site is located) with southeast- and south-oriented Smith Gulch draining the valley's south side to the Sweetwater River. To the east of the historic site Little Beaver Creek flows through a 100-meter deep valley while to the south Smith Gulch has carved a 30- to 50-meter deep valley. The south-oriented Smith Gulch valley probably eroded headward and captured Little Beaver Creek headwaters, but accepted paradigm rules make such captures difficult to explain [27]. On the other hand, new paradigm rules predict such captures occurred frequently as south-oriented flood waters carved constantly changing diverging and converging channels into a rising mountain range. Continuing in an east and southeast direction from the Fort Stambaugh historic site area several dry valleys cross the Wind River-Sweetwater River drainage divide and also drainage divides within the Sweetwater River and Beaver Creek drainage basins and indicate numerous capture events took place, which again new paradigm rules make easier to explain than accepted paradigm rules.

\subsection{Beaver Divide: Beaver-Creek-Sweetwater River Drainage Divide}

After flowing in a southeast and east direction to reach the Wind River Mountains southeast end Beaver Creek ("9" in Figure 1) turns in a north direction to flow across the Wind River Basin floor with its water eventually reaching Wind 
River Canyon. To the east of the Wind River Mountains southeast end the Beaver Creek-Sweetwater River drainage divide follows the 250-meter high Beaver Divide escarpment rim. Figure 4 provides a topographic map showing a truncated 50-meter deep valley (floor elevation 2070 meters) extending southward from the northwest-facing Beaver Divide escarpment to the shallow northeast-oriented Sweetwater River valley (not seen). The truncated valley is the widest of several such truncated valleys found along this Beaver Divide rim segment and the south-oriented drainage routes now originating near the escarpment rim suggest Beaver Divide escarpment erosion truncated multiple south-oriented valleys.

To the south of Figure 4 the truncated valley splits with a wider shallow dry valley leading in a southwest direction to meet the northeast-oriented Sweetwater River near where north-oriented Alkali Creek now joins it. The other valley branch, in which Government Meadows Draw is located, leads in a southeast direction to join the Sweetwater River. These two branches suggest prior to headward erosion of the shallow northeast-oriented Sweetwater River valley south-oriented water flowed to and then along what is now the north-oriented Alkali Creek alignment into the Great Divide Basin and probably to the Colorado River, but due to regional uplift the northeast-oriented Sweetwater River eroded its shallow northeast-oriented valley headward and beheaded and reversed flow on the Alkali Creek alignment so as to create the north-oriented Alkali Creek drainage route and the Sweetwater River-Great Divide Basin drainage divide.

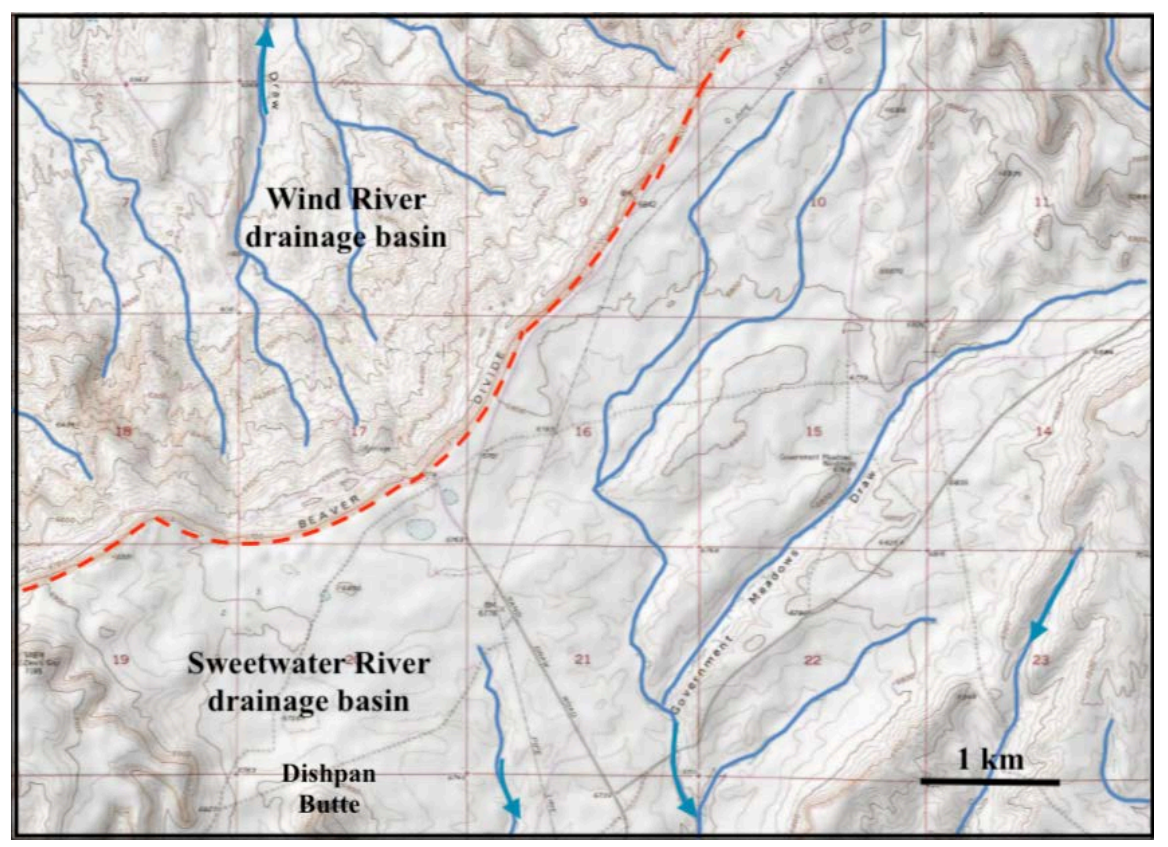

Figure 4. Modified and reduced size topographic map from USGS National Map website showing a 100-meter deep south-oriented valley now truncated by the northwest-facing Beaver Divide escarpment. The dashed red line follows the Wind River-Sweetwater River drainage divide, which is also the Beaver Divide escarpment rim. Most drainage routes are intermittent. The contour interval is 20 feet ( 6 meters). 
Mapped bedrock units [4] in Figure 4 map area are lower Eocene Wind River Formation (mudstone, sandstone and conglomerate), upper and middle Eocene Wagon Bed Formation (sandstone, siltstone, and mudstone), Oligocene and upper Eocene White River Formation (bentonitic and tuffaceous mudstone, arkose, and conglomerate), and Miocene/late Oligocene Split Rock Formation (conglomerate and well-sorted volcanic sandstone). Accepted paradigm interpretations require those sediments to have filled the Wind River Basin and to have buried the mountains through which Wind River Canyon is cut (or to a level more than 250 meters higher than Beaver Divide escarpment rim elevations in Figure 4). Most accepted paradigm interpretations of the Wind River Canyon origin require the Wind River Basin fill to have also had a north-oriented slope, which makes Figure 4 map area evidence almost impossible to explain.

Love [28] states during Oligocene time "a powerful river from the Absaroka Range continued to flow along the west margin of the Granite Mountains [to the east of Figure 4] and into the Great Divide basin ... Boulders of Tertiary igneous rocks as much as 8 feet [2.4 m.] in diameter were carried 90 miles [145 km.] or more and deposited along the stream valley." He explains present-day drainage pattern development by saying during late Pliocene or early Pleistocene time, “A broad east-trending upwarp in the southern part of the Wind River basin caused the Wind River to divert northward and its gradient to increase to several times that of the eastward flowing Sweetwater River. Headward erosion by rigorous tributaries to the Wind River was responsible for development of the Beaver Divide." In explaining the Sweetwater River course through the Granite Mountain area further to the east Love also says that in late Pliocene or early Pleistocene time, "The easterly course of the Sweetwater River was established along the trough line of the Split Rock syncline, but continued sagging of the Granite Mountains reduced the ability of this stream to erode. Thus, only 1000 feet of the buried crest of the mountains was exhumed. The sluggish river was trapped along a superimposed course across granite knobs.”

Some of Love's interpretations are consistent with the new paradigm interpretation that the southeast-oriented Wind River once joined south-oriented flood flow on the Wind River Canyon alignment to flow in a diverging and converging south-oriented channel complex across what is now the north-oriented Beaver Creek drainage basin and then into and across the Great Divide Basin. Further, Love's interpretation that uplift contributed to the Wind River diversion is consistent with new paradigm interpretation that the deep "hole's" southwest rim uplift blocked south-oriented flood flow and diverted water in east directions (such as along the Sweetwater River route) and subsequently reversed the flow direction. Perhaps because the accepted paradigm cannot provide satisfactory explanations Love does not address the multiple south-oriented valleys now truncated by the Beaver Divide escarpment and the sedimentary fill that buried the Owl Creek and Bridger Mountains to a level at least 250 meters higher than the highest Figure 4 elevations. 
From the new paradigm perspective south-oriented floodwaters emerging from Wind River Canyon upon entering the Wind River Basin area formed a south-oriented diverging and converging channel complex, which was joined by southeast-oriented flood flow channels. The combined flood flow moved in a south direction across what is today the north-oriented Beaver Creek drainage basin. Truncated through valleys such as those seen in Figure 4 were eroded by the diverging and converging flood flow channels as floodwaters moved in a south direction across what was at that time the rising deep "hole" rim. Deep "hole" rim uplift enabled the shallow east-and northeast-oriented Sweetwater River valley to erode headward across the south-oriented flood flow channels and caused flow reversals on north ends of the beheaded channels to create north-oriented Sweetwater River tributaries and the Sweetwater River-Great Divide Basin drainage divide.

The new paradigm does not require sediments to have buried the Owl Creek and Bridger Mountains. Instead Owl Creek and Bridger Mountains uplift occurred as south-oriented floodwaters flowed across them with sediments only filling the Wind River Basin to a level corresponding to the present-day Beaver Divide escarpment rim elevation. Clausen [24] identified more than 20 divide crossings along the Bighorn River-Wind River drainage divide between Wind River Canyon and the Bighorn Mountains through which south-oriented floodwaters once flowed. As the Bighorn River-Wind River drainage divide area uplift progressed the south-oriented floodwaters were channeled into fewer and fewer channels with the last two channels being through Wind River Canyon and in the Lysite Mountain area (between the Bridger and Bighorn Mountains). Eventually south-oriented flow ceased to move across the Lysite Mountain area and all south-oriented flood flow was then forced to flow through Wind River Canyon, which explains why today the Beaver Divide escarpment truncated valleys at the south end of the north-oriented Beaver Creek drainage basin (such as seen in Figure 4) represent the lowest points along today's Wind River-Sweetwater River drainage divide.

Final steps in developing the landscape seen in Figure 4 from the new paradigm perspective occurred as deep "hole" rim uplift forced a reversal of the south-oriented flood flow, which was aided by headward erosion of the northeast-oriented Yellowstone River valley (from deep "hole" space being opened up by ice sheet melting) that beheaded and reversed south-oriented flood flow moving through Wind River Canyon. That flood flow reversal created the north-oriented Beaver Creek and Wind River drainage routes leading to Wind River Canyon and set the stage for deep Wind River Basin erosion and creation of the northwest-facing Beaver Divide escarpment. South-oriented floodwaters moving to the west of the actively eroding Yellowstone River valley head were still moving in south directions across what are now high Absaroka Mountains to reach areas in the upstream (southeast-oriented) Wind River drainage basin. Wind River Mountain uplift diverted those floodwaters in southeast directions 
to the newly reversed and north-oriented Beaver Creek-Wind River drainage route. Large volumes of southeast-floodwaters flowing into the newly formed north-oriented Beaver Creek drainage basin enabled the Wind River Basin to be eroded deeper than the Sweetwater Plateau area immediately to the south, which resulted in the creation of the northwest-facing Beaver Divide escarpment.

\subsection{Beaver Divide East End: Deer Creek-Dry Creek through Valley}

The north-oriented Beaver Creek-Sweetwater River drainage divide ends a short distance to the northeast of Figure 4 although the northwest-facing Beaver Divide escarpment and the Wind River-Sweetwater River drainage divide continue in a northeast direction before turning so the escarpment faces in north, northeast, north, northeast, north, and northwest directions and eventually reaches Figure 5 map area. Throughout that distance of approximately 100 kilometers (along the escarpment rim) detailed topographic maps show at least 25 (and possibly more) truncated south-oriented valleys crossing the Wind River-Sweetwater River drainage divide (which continues to be located along the Beaver Divide escarpment rim). Between Figure 4 and Figure 5 drainage originating near those truncated valleys flows in south directions into and across the partly buried Granite Mountains before joining the east-oriented Sweetwater River.

Figure 5 provides a topographic map showing the Deer Creek-Dry Creek through valley at the Wind River-Sweetwater River drainage divide and the Beaver Divide escarpment eastern end. Deer Creek is the north- and northwest-oriented stream in the Wind River drainage basin and Dry Creek is the southeast-oriented stream in the Sweetwater River drainage basin. Lowest points

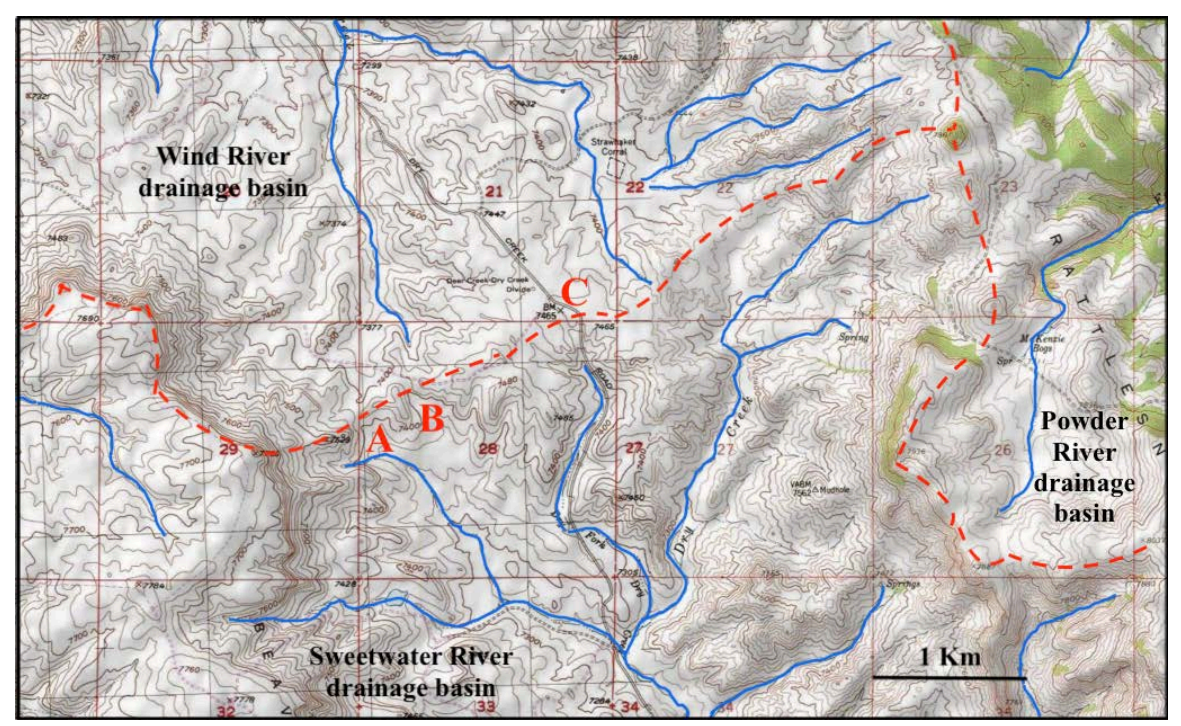

Figure 5. Modified topographic map from USGS National Map website showing the Deer Creek (north)-Dry Creek (south) through valley between the Beaver Divide escarpment eastern end and the Rattlesnake Hills. The dashed red line follows drainage divides between the identified drainage basins. Most drainage routes are intermittent. Red letters refer to divide crossings discussed in the text. The contour interval is 20 feet (6 meters). 
on the Deer Creek-Dry Creek drainage divide are 2260 meters, which are 100 meters lower than the highest east-facing Beaver Divide escarpment rim elevations immediately to the west (and almost 200 meters higher than the truncated valley floor seen in Figure 4). To the east of the Deer Creek-Dry Creek valley are the Rattlesnake Hills and the north-oriented Powder River drainage basin. Deer Creek is a north- and northwest-oriented drainage route leading to northwest-oriented Poison Creek, which flows to the Wind River. Dry Creek after flowing in a southeast direction joins the east-oriented Sweetwater River about ten kilometers west of where the Sweetwater River turns in a south direction to join the North Platte River (as a barbed tributary).

A possible accepted paradigm interpretation might be the Deer Creek-Dry Creek through valley had been eroded by a south-oriented tributary before the Wind River was captured and diverted to flow in a north direction. However, Wind River Canyon rim elevations are significantly higher than the Deer Creek-Dry Creek through valley floor elevation, making it almost impossible to explain how the Wind River was diverted to the north if a south-oriented Wind River tributary eroded the Deer Creek-Dry Creek through valley. The accepted paradigm problem becomes more complicated by trying to explain how the 25 or more truncated valleys located on the Wind River-Sweetwater River drainage divide stretch between the north-oriented Beaver Creek drainage basin and the north-oriented Deer Creek valley. Elevations along that drainage divide stretch are much lower than the Wind River Canyon rim elevations and there is no simple accepted paradigm explanation for how the Wind River was diverted to flow through Wind River Canyon if it once had 25 or more south-oriented tributaries flowing at significantly lower elevations.

Massive south-oriented flood flow moving in diverging and converging channels provides a simple new paradigm explanation for the more than 25 divide crossings located between north-oriented Beaver Creek drainage basin and north-oriented Deer Creek. As stated more than 20 divide crossings to the east of Wind River Canyon show where south-oriented floodwaters once flowed from the Bighorn Basin into the Wind River Basin and those floodwaters logically would have continued in diverging and converging channels as the water moved in a south direction across the Wind River Basin. According to the new paradigm interpretation the Wind River diversion occurred due to a reversal of south-oriented flood flow, which is simpler than accepted paradigm explanations requiring burial of the Owl Creek and Bridger Mountains. To the north of Figure 5 is the Lysite Mountain area, which has the lowest divide crossings along the Bighorn-Wind River drainage divide between Wind River Canyon and the Bighorn Mountains. Clausen [24] interprets the Lysite Mountain area as a place where large south-oriented floods flowed from the Bighorn Basin into the Wind River Basin. Based on that new paradigm interpretation the Deer Creek-Dry Creek route originated as a major south-oriented flood flow channel that continued in a south direction along the present-day Dry Creek alignment. 


\section{Discussion}

One paradigm cannot be used to judge another because paradigms use fundamentally different rules when interpreting the same set of evidence, however Occam's Razor provides a useful paradigm evaluation tool. Anderson [29] in describing Occam's Razor suggests in science, "What can be done with fewer [assumptions] is done in vain with more." Both paradigms compared here require the Wind River Basin to have been deeply eroded by north-oriented Wind River tributaries. Accepted paradigm interpretations require a Wind River Basin sediment fill sufficient to have buried the Owl Creek and Bridger Mountains to a level higher than today's Beaver Divide escarpment rim elevations in order to erode Wind River Canyon. For this reason, accepted paradigm interpretations are complicated because they require north-oriented Wind River tributaries to not only remove the sediment fill needed to bury the Owl Creek and Bridger Mountains, but also to remove sediments that once filled the Wind River Basin to the Beaver Divide escarpment rim elevation level. In contrast new paradigm interpretations are simpler because they have no need to remove sediments that once buried the Owl Creek and Bridger Mountains and can explain the north-facing Beaver Divide escarpment erosion by a massive reversal of south-oriented flood flow that had been flowing through Wind River Canyon.

While the new paradigm provides more complete and simpler explanations (at least for topographic map evidence described here) the question can be asked, how does the new paradigm explain other types of evidence such as the Eocene, Oligocene, Miocene, Pliocene, and Pleistocene sediments that previous workers used when developing accepted paradigm interpretations? Even though those sediments and their relative positions represent paradigm neutral evidence, those sediments and relationships can be interpreted in different ways. While beyond the scope of this paper massive south-oriented continental ice sheet melt water floods could have transported and deposited some or all of those sediments. The terms Eocene, Oligocene, Miocene, Pliocene, and Pleistocene, probably also have different absolute time meanings depending on which paradigm is used. Unlike the new paradigm the accepted paradigm requires long periods of absolute time to erode mountains, fill intermontane basins and bury mountain ranges, and then to excavate the filled intermontane basins and to exhume the buried mountain ranges. Instead the new paradigm requires much shorter absolute time periods to rapidly carve deep valleys into rising mountain ranges and a mechanism that explains why mountain ranges and plateau areas were uplifted as massive south- and southeast-oriented floods flowed across them. That mechanism is a thick continental ice sheet heavy enough to raise a deep "hole" rim and mountain ranges and plateau areas while large meltwater floods flowed across them.

\section{Conclusion}

In conclusion much more complicated explanations are needed to explain the 
same Wind River-Sweetwater River drainage divide area topographic map evidence from the accepted paradigm perspective than from the new paradigm perspective. Occam's Razor states that in science the paradigm offering the simplest explanations should be preferred. Results of this new paradigm test are sufficiently successful that further new paradigm testing is needed and justified.

\section{Acknowledgements}

Arthur Strahler, then at Columbia University and Brainerd Mears, Jr., then at the University of Wyoming, during the 1960s, introduced the author to numerous unsolved drainage history problems. Preliminary work leading up to the new paradigm development was done while employed as a faculty member at Minot State University where library staff members, other faculty members, and students greatly assisted in providing access to the needed detailed topographic maps.

\section{Conflicts of Interest}

The author declares no conflicts of interest regarding the publication of this paper.

\section{References}

[1] Kuhn, T.S. (1970) The Structure of Scientific Revolutions. 2nd Edition, University of Chicago Press, Chicago, IL, 210 p.

[2] Clausen, E. (2018) Deep Erosion by Continental Ice Sheets: A Northern Missouri River Drainage Basin Perspective: North America. Current Research in Geoscience, 8, 27-38. https://doi.org/10.3844/ajgsp.2018.27.38

[3] Love, J.D. and Christiansen, A.C. (1985) Geologic map of Wyoming: United States Geological Survey, Wyoming State Geological Survey Release, 2014.

[4] Johnson, J.F. and Sutherland, W.M. (2009) Geologic Map of the Lander 30' x 60' Quadrangle, Fremont County, Wyoming. Wyoming State Geological Survey, Map Series.

[5] Lohman, K.E. and Andrews, G.W. (1968) Late Eocene Nonmarine Diatoms from the Beaver Divide area, Fremont County, Wyoming. United States Geological Survey Professional Paper 593-E, 1-26. https://doi.org/10.3133/pp593E

[6] Bauer, C.M. (1934) Wind River Basin. Bulletin of the Geological Society of America, 45, 665-695. https://doi.org/10.1130/GSAB-45-665

[7] Mears Jr., B. (1993) Geomorphic History of Wyoming and High-Level Erosion Surfaces. In: Snoke, A.W., Steidtmann, J.R. and Roberts, S.M., Eds., Geology of Wyoming. Geological Survey of Wyoming Memoir No. 55, Laramie, Wyoming, 608-626.

[8] Lillegraven, J.A. and Ostresh Jr., L.J. (1988) Evolution of Wyoming's Early Cenozoic Topography and Drainage Patterns. National Geographic Research, 4, 303-327.

[9] Galloway, W.E., Whiteaker, T.L. and Ganey-Curry, P. (2011) History of North American Drainage Evolution, Sediment Yield, and Accumulation in the Gulf of Mexico Basin. Geosphere, 7, 938-973. https://doi.org/10.1130/GES00647.1

[10] Sinclair, W.J. and Granger, W. (1911) Eocene and Oligocene of the Wind River and 
Bighorn Basins: American Museum of Natural History Bulletin, 30, 84-117.

[11] Mackin, J.H. (1937) Erosional History of the Bighorn Basin, Wyoming. Geological Society of America Bulletin, 48, 813-894. https://doi.org/10.1130/GSAB-48-813

[12] Riihimaki, C.A., Anderson, R.S. and Safran, E.B. (2007) Impact of Rock Uplift on Rates of Late Cenozoic Rocky Mountain River Incision. Journal of Geophysical Research, 112, F03S02. https://doi.org/10.1029/2006JF000557

[13] Howard, A.D. (1960) Cenozoic History of Northeastern Montana and Northwest North Dakota with Emphasis on the Pleistocene. United States Geological Survey Professional Paper 326, 107. https://doi.org/10.3133/pp326

[14] Jackson, L. (2018) The Paleo-Bell River: North America's Vanished Amazon. Earth, 63, 74-81.

[15] White, W.A. (1972) Deep Erosion by Continental Ice Sheets. Geological Society of America Bulletin, 83, 1037-1056. https://doi.org/10.1130/0016-7606(1972)83[1037:DEBCIS]2.0.CO;2

[16] Gravenor, C.P. (1975) Erosion by Continental Ice Sheets. American Journal of Science, 275, 594-604. https://doi.org/10.2475/ajs.275.5.594

[17] Sugden, D.E. (1976) A Case against Deep Erosion of Shields by Continental Ice Sheets. Geology, 4, 580-582. https://doi.org/10.1130/0091-7613(1976)4<580:ACADEO>2.0.CO;2

[18] Clausen, E. (2018) Geomorphic History of the Beaver Creek Drainage Basin as Determined from Topographic Evidence: Eastern Montana and Western North Dakota. Journal of Geography and Geology, 10, 79-91. https://doi.org/10.5539/jgg.v10n3p79

[19] Clausen, E. (2019) Origin of the Redwater River Drainage Basin Determined by Topographic Map Interpretation: Eastern Montana, USA. Journal of Geography and Geology, 11, 42-54. https://doi.org/10.5539/jgg.v11n1p42

[20] Clausen, E. (2018) Probable Deep Erosion by Continental Ice Sheet Melt Water Floods: Chalk Buttes Area of Carter County, Montana, USA. International Journal of Geography and Geography (Conscientia Beam), 7, 14-26. https://doi.org/10.18488/journal.10.2018.71.14.26

[21] Clausen, E. (2018) Topographic Analysis of Laramie Range Bedrock-Walled Canyon Complex and the Goshen Hole Escarpment-Surrounded Basin, Albany and Platte Counties, Southeast Wyoming, USA. Open Journal of Geology, 8, 33-55. https://doi.org/10.4236/ojg.2018.81003

[22] Clausen, E. (2018) Topographic Map Analysis of High Elevation Black Hills through Valleys Linking Spearfish and Rapid Creek Headwaters Valleys, Lawrence County, South Dakota, USA. Journal of Geography and Geology, 10, 8-21. https://doi.org/10.5539/jgg.v10n1p8

[23] Clausen, E. (2019) Upper Sun River Drainage Basin Origin Determined by Topographic Map Interpretation Techniques: Lewis and Clark and Teton Counties, Montana, USA. Open Journal of Geology, 9, 257-277. https://doi.org/10.4236/ojg.2019.95018

[24] Clausen, E. (2019) Topographic Map Interpretation of the Bighorn River-Wind River Drainage Divide Area Located East of Wyoming' Wind River Canyon. Universal Journal of Geoscience, 7, 56-67.

[25] Steidtmann, J.R., Middleton, L.T. and Shuster, M.W. (1989) Post-Laramide (Oligocene) Uplift in the Wind River Range, Wyoming. Geology, 17, 38-41.

https://doi.org/10.1130/0091-7613(1989)017<0038:PLOUIT >2.3.CO;2 
[26] Baker, V.R. (1981) Large-Scale Erosional and Depositional Features of the Channel Scabland. In: Baker, V.R., Ed., Catastrophic Flooding. The Origin of the Channeled Scabland, Dowden, Hutchinson and Ross, Inc., Stroudsburg, 276-310.

[27] Bishop, P. (1995) Drainage Rearrangement by River Capture, Beheading and Diversion. Progress in Physical Geography, 19, 449-473. https://doi.org/10.1177/030913339501900402

[28] Love, J.D. (1970) Cenozoic Geology of the Granite Mountains Area, Central Wyoming. United States Geological Survey Professional Paper 495-C, 154 p. https://doi.org/10.3133/pp495C

[29] Anderson, D.L. (2002) Occam's Razor: Simplicity, Complexity, and Global Dynamics. Proceeding of the American Philosophical Society, 146, 56-76. 